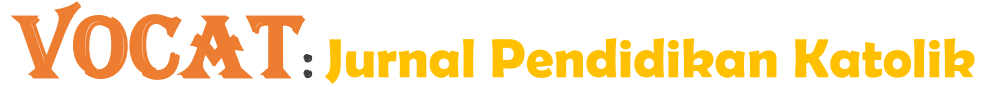

Website: https://ejournal.stakatnpontianak.ac.id/index.php/vocat

Vol. 1, No. 1 Tahun 2020,

Hal. 22 - 29

\section{MASYARAKAT BAKATEU HIDUP DALAM KEBERAGAMAN TANPA KONFLIK SELAMA 45 TAHUN}

\author{
Marianus Teti \\ Afiliasi: STAKat Negeri Pontianak, Program Magister Teologi Katolik \\ Email: Marianus123@gmail.com
}

\begin{abstract}
Riwayat Artikel
Abstrak

Dikirim : 12 Agustus 2020

Direvisi : 8 September

Diterima : 22 September 2020

Penelitian ini bertujuan untuk mengetahui bagaimana kehidupan kerukunan umat beragama Katolik-Islam selama 45 tahun di Bakateu. Metode penelitian yang digunakan adalah penelitian kualitatif dengan pendekatan deskriptif kualitatif. Penelitian dilakukan selama enam bulan (Januari-Juni 2018). Terdapat empat hal yang membuat masyarakat Bakateu bertahan selama 45 tahun dan tidak pernah terjadi konflik antarumat beragama, yaitu semangat kekeluargaan, semangat persahabatan dan pelayanan, semangat solidaritas dan semangat gotong royong. Keempat hal ini terjadi karena adanya suatu komunikasi jiwa sehingga kedamaian, kerukunan, sikap saling menghargai dan menghormati satu sama lain dipelihara dan dijaga oleh masyarakat Bakateu sebagai masyarakat yang berbudaya dan beragama.

Tidak terjadinya konflik antarumat beragama karena adanya semangat kekeluargaan, semangat persahabatan dan pelayanan, semangat solidaritas dan semangat gotong royong yang dibina semenjak awal keberagaman hingga kini. Saya berharap ada peneliti lain yang bisa melakukan penelitian lanjutan atau penelitian pengembangan untuk melihat lebih jauh lagi tentang dampak lain dari hubungan antarumat beragama di Bakateu dan di tempat lainnya.
\end{abstract}

Kata Kunci: Masyarakat, Keberagaman, Konflik

\begin{abstract}
Abtract
This study aims to determine how the life of Catholic-Muslim harmony for 45 years in Bakateu. The research method used is qualitative research with a qualitative descriptive approach. The study was conducted for six months (January-June 2018). There are four things that have made the Bakateu community survive for 45 years and there have never been any conflicts between religious believers, namely the spirit of kinship, the spirit of friendship and service, the spirit of solidarity and the spirit of mutual cooperation. These four things happen because of the existence of a communication of the soul so that peace, harmony, mutual respect and respect for one another are maintained and maintained by the Bakateu community as a cultured and religious society.

There is no conflict between religious believers due to the spirit of kinship, the spirit of friendship and service, the spirit of solidarity and the spirit of mutual cooperation which has been fostered since the beginning of diversity until now. I hope there are other researchers who can carry out further research or development research to see further about the other impacts of inter-religious relations in Bakateu and elsewhere.
\end{abstract}

Keywords: Society, Diversity, Conflict

\section{PENDAHULUAN}

Negara Indonesia merupakan negara yang sangat beragam dalam agama, budaya, suku ras, status social, dll. Keberagaman sering dipandang sebagai perbedaan dan perbedaan semakin dipertajam serta sering dimanfaatkan sebagian orang untuk memenuhi ambisi dan kepentingan pribadi atau golongannya. Hal Ini menimbulkan konflik horizontal yang menyebabkan terpuruknya bangsa Indonesia, dan terjadinya kerusuhan dimana-mana.
Manipulasi simbol-simbol keagamaan pun turut berandil dalam melahirkan konflik antar agama. Khasanah budaya Indonesia yang toleran diobrak-abrik oleh narasi-narasi keagamaan yang mengganggu keutuhan Pancasila dan semangat toleransi yang telah sekian lama dijunjung tinggi.

Penelitian tentang perjuangan umat Islam Pribumi di Keo, Flores Tengah (NTT) untuk menjawab pencarian bagaimana mempertahankan identitas diri yang majemuk baik sebagai Muslim maupun sebagai 
masyarakat adat yang berkomitmen pada budaya lokal tertentu (Tule, 2014).

Masyarakat Bakateu hidup dalam keberagaman agama, bahasa, suku, status social, dan lain-lain. Oleh karena itu, semangat toleransi antarumat beragama harus dijunjung tinggi dalam semangat Pancasila sebagai landasan ideologi. Pertanyaanya adalah bagaimana masyarakat Bakateu mengahapi bentuk keberagaman agama?

Keadaan sosial atau situasi sosial terjadi di dalam negara, masyarakat, keluarga luas (extended family), keluarga batih (nuclear family). Setiap peristiwa yang terjadi dalam masyarakat membutuhkan interaksi atau hubungan timbal balik antar sesama anggota kelompok baik secara horisnotal maupun vertikal.

Secara sosiologis, maka apabila terjadi interaksi sosial yang berulang kali sehingga terjadi pola-pola tertentu, maka akan timbul kelompok sosial. Kelompok sosial tersebut merupakan himpunan atau kesatuan orang-orang yang mempunyai kepentingan bersama yang sedemikian eratnya, sehingga masing-masing anggota kelompok merasa menjadi bagian dari kelompok sosial sebagai suatu kesatuan yang utuh.

Keberagaman merupakan suatu harmoni dalam kehidupan. Keberagaman sering dipandang sebagai perbedaan dan perbedaan semakin dipertajam serta sering dimanfaatkan sebagian orang untuk memenuhi ambisi dan kepentingan pribadi atau golongannya (Dwintari 2018).

Dialog antarumat beragama dipandang sebagai resolusi konflik. Dialog antar agama Katolik-Islam adalah suatu komunikasi jiwa antar pribadi maupun kelompok dari agama Katolik dan Islam untuk menemukan jalan kedamaian secara terbuka.

Manusia adalah makluk konfliktis (Rosana 2015). Penyebab terjadinya konflik adalah perbedaan latar belakang kedua belah pihak hingga terjadi konflik, perbedaan kepentingan diantara individu dalam kelompok/ masyarakat yang kesemuanya saling terkait dalam realita sosial yang kompleks. Konflik bukanlah sesuatu yang harus dihindari, dianggap momok yang menakutkan dalam kehidupan bermasyarakat yang dipandang sebagai dinamisator dalam setiap aktifitas organisasi itu sendiri, tanpa konflik organisasi akan mati dan dengan adanya konflik organisasi akan hidup dan berkembang (Wahyudi 2015).

\section{METODE}

Lokasi dalam penelitian ini adalah dusun BakateuDesa Wehali-Kecamatan Malaka Tengah-Kabupaten Malaka-Provinsi Nusa Tenggara Timur. Secara jelas dapat dilihat pada gambar maps dibawah ini.

Gambar: Lokasi Bakateu

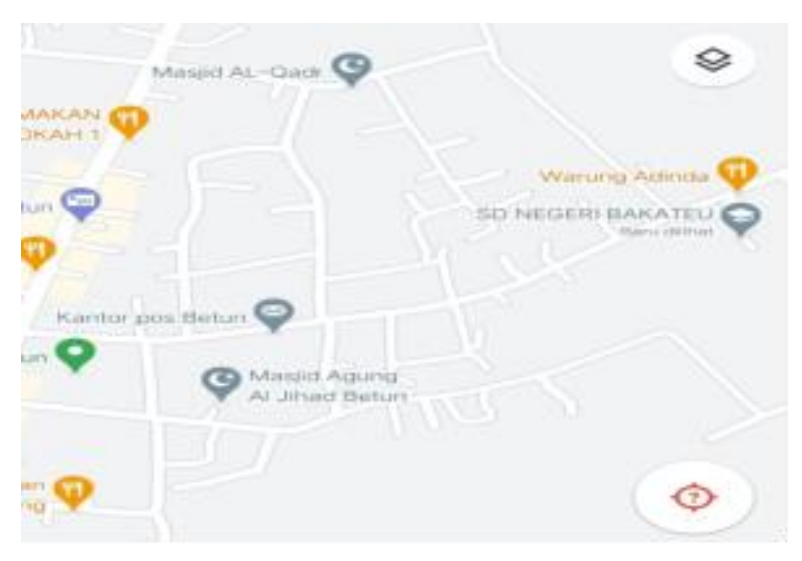

Sumber: Hasil screnshot dari google maps

Lokasi Bakateu mulai dari Masjid Agung Al Jihad Betun-SD Negeri Bakateu. Umat Katolik dan Islam Bakateu mendiami sepanjang jalan dari Mesjid menuju SD. Di seberang jalan dihuni oleh umat Katolik dan Islam lainnya.

Keadaan umat beragama dalam masyarakat Bakateu dapat dilihat pada table berikut:

Tabel: Jumlah penduduk Bakateu berdasarkan Agama

\begin{tabular}{|l|l|r|r|r|}
\hline No & Agama & \multicolumn{1}{c|}{ L } & \multicolumn{1}{c|}{ P } & \multicolumn{1}{c|}{ Jlh Jiwa } \\
\hline 1 & Katolik & 491 & 609 & 1100 \\
\hline 2 & Protestan & 20 & 32 & 52 \\
\hline 3 & Islam & 43 & 60 & 103 \\
\hline \multicolumn{2}{r|}{ Jlh } & $\mathbf{5 5 4}$ & $\mathbf{7 0 1}$ & $\mathbf{1 2 5 5}$ \\
\hline
\end{tabular}

Sumber: Data Dusun Bakateu dan olahan Penulis

Metode penelitian yang digunakan dalam penelitian ini adalah penelitian kualitatif (Lexy J. Moleong 2019) dengan pendekatan kualitatif deskriptif (Husaini 2008). Selama enam bulan (Januari-Juni 2018) saya melakukan observasi terhadap kehidupan masyarakat Bakateu dan wawancara terhadap tokoh agama, tokoh adat dan pemerintah setempat, yaitu Kepala Dusun dan Ketua Rukun Warga (RW).

\section{HASIL DAN PEMBAHASAN}

Saya bertemu dengan bapak Antonius Kali di rumahnya. Ketika saya tiba di rumahnya pada sore itu, bapak Anton sedang memberi makan kepada ternak peliharaannya (babi dan ayam). Kemudian bapak Anton dipanggil oleh isterinya dan akhirnya saya 
bertemu dengan dia. Kami bertemu dan membicarakan maksud kedatangan saya sesuai dengan surat pemberitahuan yang saya kirimkan lebih dahulu. Saat saya bertanya mengenai kehidupannya selama ini dengan umat Islam dan kehidupan masyarakat Bakateu umumnya dengan agama Islam. Ia tertawa dan sambil tersenyum, raut wajahnya sangat menggembirakan. Ia menceritakan banyak hal, diantaranya adalah:

"Ha'u ko ema Islam sia di'ak ho malu dein. Ha'u ba karian ema Islam siakan uma, tan ha'u tukang. Ha'u ba karian siakan uma tan ami hare malu di'ak, sia nare ami di'ak foin bele naruka ha'u ma'ak karian siakan uma. Nia tenik ami karian harewe te' $i k$ ba malu, dadi ami hare malu di'ak dein. Ami dakar malu nu'u keluarga tan ami moris ho malu iha rai Bakateu". Hubungan saya dengan umat Islam sangat baik. Saya mengerjakan rumah orang Islam. Hubungan kami baik baru mereka percayakan saya untuk mengerjakan rumah mereka. Dan juga kami bekerja sawah berdampingan, kami sangat rukun dan damai. Kami saling menjaga sama seperti keluarga. Hal ini terjadi karena adanya komunikasi antarpribadi yang intens (Alo 1991).

Ami biasa saat taman hare oan, kalo amikan hare oan la to'o berarti ema Islam sia fo siakan hare oan ba ami, ami mos nunia, kalo sirakan hare oan la to'o berarti ami fo hare oan ba sira. Fo hare oan ba malu ne'e fo du'uk dein, fo hodi neon no laran, lia hadomi malu tan ita moris kahur malu, tur kahur malu no tenik karian ho malu". Saat musim tanam padi, ketika ada anakkan padi yang lebih maka saya berikan kepada umat Islam yang membutuhkan, mereka juga melakukan hal yang sama karena sawah kami berdampingan. Pemberian anakkan padi itu secara gratis tanpa pembayaran. Karena kita tinggal berdampingan maka harus saling membantun satu sama lain.

"Oras hatama we ba harewe, kalo ha'u maak ba katama we berarti ha'u katama no ba sirak'an, kalo sira maak ba ratama berarti ratama no ba amikan, lele mos ami hatama fo let ba malu, balu natama uluk foin rumak sia osak. No tenik ba loron dakar manu lamin, kalo ha'u mak ba uluk bararti kesi no bodik sirak'an, kalo sira ma'ak ba uluk berarit rare no amikan." Saat mengairi sawah, jika saya yang pergi lebih dahulu untuk mengairi sawah maka sawah-sawah umat Islam yang berdekatan juga saya alirkan airnya. Atau kami saling memberi kesempatan satu sama lain, membagi jadwal untuk mengairi sawah. Dan juga saat musim jaga burung pipit di sawah, ketika saya yang lebih dahulu pergi maka saya juga menjaga padinya mereka demikianpun dengan mereka.

"Ami moris ne'e di'ak dein. Kalo no loron adat atau no ema maten, ema Islam sia rona los dein mai ti'an. Ita sedauk ba katak sira mos sira mai ti'an. Ami mos nunia, kalo no adat atau acara kona ba sira mos ami ba ti'an. Sira mai fo sumbangan no sia namulak tuir sirakan fafiar a". Hidup kami sangat rukun dan damai, jika ada acara adat atau orang meninggal, mereka hanya dengar saja sudah datang. Kami juga melakukan hal yang sama. Umat Islam di Kompleks kami datang dengan sendirinya sambil membawa sumbangan dan mendoakan jiwa orang yang meninggal sesuai dengan agamanya.

"Ami iha rai Bakateu ne'e no suku kabau. Uma adat maktaen, uma adat umakatuas no uma adat uma tasi Lalor. Kalo ami halo adat bodik hamis, adat nu'u tasena maufinu, ami mos halo bodik no ba sira tan ami hein ho malu iha Rai Bakateu. Ema Islam iha Bakateu ne'e la wa'in. Wa'in a mak iha Pasar Lama no Pasar Baru. Mais Pasar lama no pasar baru ne'e ami fo kladik ba malu hodi dalan dein, dadi ami moris di'ak hotu ho malu." Di Bakateu terdapat tiga rumah adat yaitu rumah adat Maktaen, Uma Katuas dan Uma Tasi Lalor. Saat upacara makan jagung muda dan upacara untuk mebentengi kampung dari musuh atau penyakit, kami juga mendoakan bagi mereka karena kami hidup sama-sama di wilayah Bakateu.

"Hori ema Islam sia tama iha Rai Malaka, Rai Betun to'o tenik tama iha Rai Bakateu, ema Islam sia ro ami di'ak-di'ak dein. Ami la pernah halo salah ba malu”. Semenjak umat Islam memasuki tanah MalakaBetun dan juga memasuki wilayah Bakateu, umat Islam dengan Katolik di Bakateu sangat rukun. Kami tidak pernah terjadi konflik.

Gabriel T. Nahak, memberikan ceritanya bahwa selama dia berada di Bakateu dan menjabat sebagai Kepala Dusun, ia belum pernah bahkan tidak melihat konflik antarumat beragama Katolik dengan Islam, Islam dengan protestan atau Katolik dengan Protestan. Selama ini ia melihat bahwa masyarakat Bakateu hidup sangat rukun. Mereka hidup saling berdampingan, kami hidup bersama. Semua agama berhak untuk ada dan hidup. Secara sosial, kita harus belajar untuk toleran dan bahkan menghormati iman atau kepercayaan dari penganut agama lainnya (Widjaja 2019). 
Bentuk-bentuk kebersamaan kami di masyarakat Baketu ini adalah salah satunya kerja sawah secara bersama, saling menghargai dan menghormati. Ketika ada yang mengari sawahnya maka kami yang lain menunggu. Kami tidak katakana bahwa, kamu minoritas jadi kamu harus tunggu, kamu itu pendatang jadi kamu kemudian.

Masyarakat saya hidup selalu damai. Saya dan umat Islam itu sama seperti keluarga, kami tidak saling menjatuhkan. Bantuan pemerintah dibagikan kepada masyarakat tanpa membedakan apa agamamu, darimana sukumu. Saya memberikan kepada masyarakat sesuai dengan apa yang mereka butuhkan.

Ketika saya bertanya mengenai tanggapannya terhadap isu-isu yang beredar di media social terkait masalah keagamaan, ia mengatakan bahwa saya dan masyarakat saya tidak terprovokasi dengan isu-isu atau masalah-masalah seperti pembakaran Gereja, penutupan tempat ibadah, pelemparan masjid atau moshola, dll. Masyarakat saya sangat dewasa dalam menyikapi hal seperti ini. Apabila dikemudian hari ada konflik antarumat beragama Islam dan Katolik, atau konflik antarumat beragama manapun maka saya sebagai kepala dusun akan memanggil orang-orang penting dari agama-agama yang berkonflik itu agar masalahnya dapat diselesaikan.

Namun, hingga saat ini tidak pernah terjadi konflik atau masalah atarumat beragama di Bakateu. Kami saling menjaga, menghormati dan menghargai. Ketika umat Islam merayakan hari rayanya maka umat Katolik dan umat beragama lainnya menjaga ketenangan dan keamanan diri agar tidak mengganggu upacara keagamaan mereka.

Selain itu, terdapat kerja sama antar umat beragama Katolik dengan Islam. Bentuk kerja sama itu adalah ada pekerjaan tukang, kerja sawah, dan sesuai dengan profesi dan kesepakatan mereka.

Menurut Serfina Balok Seran, semenjak saya lahir di Bakateu hubungan keluarga saya dengan umat Islam sangat baik. Kami itu hidup seperti saudara, kami saling melayani satu sama lain. Orang Islam biasa undang saya untuk pergi masak di acara mereka. Mereka undang saya itu seperti acara cukur rambut anak. Saya juga sekali-sekali membantu membersihkan rumah mereka dan mereka memberikan saya upah. Hubungan persaudaraan antarumat beragama itu sangat tulus, setara dan terbuka (Rifa'i 2017).

Pernah terjadi kebakaran di pasar Bei Abuk dan rumah umat Islam turut terbakar. Kami dari masyarakat Bakateu pergi membantu umat Islam dan membersihkan rumah mereka dari kebakaran. Barangbarang mereka ada yang di titipkan di rumah kami.

Bentuk kebersamaan kami lainnya adalah ketika kasus Timor-Timur di Suai, beberapa umat Islam sangat ketakutan dan sampai menginap dan barang milik mereka dititipkan di rumah kami. Saya dan keluarga saya tidak membeda-bedakan kamu itu agama apa atau dari mana asal kamu. Kita ini adalah saudara, kita tinggal berdampingan jadi kita harus saling membantu.

Hal lain juga dikatakan oleh Natalia Y.S Kefi, dia mengatakan bahwa kami di Bakateu ini aman-aman saja. Kami dengan umat Islam hidup seperti keluarga. Umat Islam sangat baik dengan kami. Dia mengatakan bahwa, saat umat Islam merayakan hari rayanya maka kami dari umat Katolik menjaga ketengan dan kenyamanan, jadi umat Islam dapat merayakannya dengan sukacita.

Bentuk kebersamaan kami di Bakateu adalah ketika ada acara atau hajatan maka kami pergi tanpa sebelum diberitahukannya. Ketika kami kena acara atau adat maka umat Islam datang memberi sumbangannya, kami juga melakukan hal yang sama. Kami juga bekerja sawah berdampingan jadi kami selalu dan saling menjaga agar jangan sampai terjadi masalah di antara kami. Itu yang kami selalu jaga dan pelihara selama ini.

Emirentiana Luruk menambahkan bahwa kehidupan umat beragama Katolik dan Islam di Bakateu sangat rukun dan damai. Dia melihat bahwa kerukunan dan kedamaian ini bisa terjadi katena kami saling memahami, saling mengerti dan saling menghargai satu sama lain. Kami tidak memandang dari segi agama tetapi kami melihatnya dari segi persahabatan dan persaudaraan sebagai satu keluarga besar di Bakateu.

Umat Islam dan Katolik yang berprofesi sebagai petani, mereka bekerja sawah berdampingan. Jika tidak saling menghargai dan menghormati maka akan sangat susah. Mengapa? Karena disaat kita mau mengalirkan air ke sawah, otomatis kita akan terjadi konflik karena saling merampas air. Kasus air ini sering terjadi di tempat lain walaupun dari agama dan suku yang sama.

Ketika saya bertemu dengan tokoh-tokoh dari agama Islam, mereka bercerita dengan sukacita dan sangat memuji kerukunan dan kedamaian yang terjadi di Kabupaten Malaka umumnya dan lebih khususnya di Bakateu. Pada umumnya mereka sangat bergembira 
karena walaupun mereka minoritas tetapi mereka diterima dan diberlakukan dengan sangat baik. Inilah ungkapan tokoh-tokoh agama Islam saat diwawancarai.

Zainal Mutaqin, ketua MUI Kab. Malaka, saat saya mewawancarai mengenai kehidupan dan hubungan umat Islam dengan Katolik selama ini dan ia mengatakan bahwa, sikap saya terhadap umat beragama lain adalah toleransi kepada siapa saja. Karena sikap toleransi akan menuju sikap persatuan yang tidak bisa dipisahkan dari agama lain. Kita harus menghindari suara-suara provokasi yang datang merusak kerukanan kita. Hal ini juga dikatakan ole Alo Liliweri bahwa konflik itu terjadi karena adanya penyebaran isu dan adanya prasangka buruk (Liliweri 1991). Agama tanpa otonomi, dan bahkan yang secara sengaja dipolitisasi oleh sejumlah elite politik dan kelompok-kelompok fanatik, akan secara mudah menyulut terjadinya konflik-konflik agama (Tule 2014).

Sunarso menambahkan bahwa tetap saling menjaga toleransi yang selama ini sudah terjalin sesuai dengan Bhineka Tunggal Ika. Saya tidak membedabedakan satu agama dengan agama lain dalam pergaulan. Ajaran Islam adalah untuk menyayangi agama lain.

Sementara Ibrahim Abdur Kadir mengatakan bahwa ia melihat agama lain itu sama seperti saudara kandung, menghargai, menghormati, menyayangi walaupun dalam kaidah-kaidah tertentu kita berbeda namun kita sama. Muhammad Yunus mengatakan bahwa " Hasoru malu, dale ho malu, hase malu, dakar malu-lituk malu. Fo neon no laran ba malu, iha agama lima ne laran ita mesti di'ak ho malu". Saling menyapa, saling menghargai, saling menjaga. Saling menghargai karena di dalam lima agama ini sama jadi harus saling rukun.

H. Muhammad Tang mengatakan bahwa saya melihat mereka itu seperti keluarga, karena semenjak saya dari Atambua ke Betun menggunakan Kuda, dan kuda saya diikatkan di lahannya orang Katolik. Mereka sangat baik kepada saya dan keluarga saya. Hubungan saya dengan umat Katolik itu sudah seperti keluarga.

Abud Ahmad mengatakan bahwa, semenjak umat Islam Masuk di Malaka-Betun pada tahun 1958 dan mulai menyebar di beberapa daerah di Malaka yaitu Manumuti, Kletek, Bolan dan Bakateu serta wilayah sekitaran Pasar Betun. Umat Islam masuk di Bakateu pada tahun 1970-an setelah banjir besar melanda Malaka bagian Fehan. Pada tahun 1975, masjid di Manumuti dipindahkan ke Bakateu.

H. Muhammad Tang mengatakan bahwa, toleransi dan kerukunan antarumat bergama sudah dilakukan selama umat Islam belum begitu banyak mendiami Rai Malaka, ketika pembangunan Masjid, raja Wehali (salah satu kerajaan di Kab. Malaka-berbatasan dengan Kota Betun) bersama umat Katolik lainnya datang membantu pembangunan Masjid. Ini adalah salah satu bentuk toleransi yang nyata dan perlu ditiru oleh daerah lain.

Sunarso mengatakan, toleransi di RT saya yaitu di RT 19, kami mengadakan pesta kebersamaan yaitu saat hari Raya Natal dan tahun baru serta hari raya Idul fitri secara bersama-sama. Kami sangat senang dan akrab dengan kerukunan ini. Apa yang dikatakan sunarso dan apa yang dilakukan pada RT 19 ini merupakan suatu pembentukan adaptasi budaya (Utami 2015).

Sunarso menambahkan, ada beberapa umat Katolik yang dapat belajar dengan baik pada umat Islam. Contohnya ada yang dengan saya sedang belajar cara membuat batu bunga, ukir-ukir di meubel. Kami saling menghargai dan mnehormati satu sama lain. Hal ini merupakan suatu komunikasi interaksi simbolik yang dengan rendah hati membagi pengetahuan dan keterampilan yang ia miliki (Laksmini 2017) .

Berdasarkan hasil temuan di atas, terdapat empat hal yang menunjang kehidupan keberagaman masyarakat Bakateu hidup dalam keberagaman tanpa konflik antarumat beragama. Keempat hal itu antara lain: semangat kekeluargaan, semangat persahabatan dan pelayanan, semangat solidaritas antar masyarakat dan semangat gotong royong.

Pertama, semangat kekeluargaan. Keluarga bisa dikatakan hubungan antara suami-isteri dan anakanak dan juga keluarga sebagai hubungan social dalam masyarakat (Rahayu 2012). Semangat kekeluargaan ini terlihat dalam hasil wawancara dengan para narasumber. Bentuk dari semangat kekeluargaan ini antara lain: 1) memiliki perasaan senasib dan sepenanggungan, 2) memiliki rasa persaudaraan yang tinggi, 3) memiliki semangat cinta kasih yang mendalam dan, 4) perasaan saling memiliki.

Saya juga mewawancarai seorng tokoh adat di Paroki Santa Maria Fatima Betun mengenai budaya masyarakat Fehan. Masyarakat Fehan menggunakan bahasa kiasan kananukl pantun sebagai bentuk ungkapan perasaan atau isi hatinya baik itu dalam 
kegembiraan, kesedihan, memberi pujian bahkan memberi sindiran.

Tentang semangat kekeluargaan dalam hidup beragama, Hendrikus Klau mengungkapkan kananuk seperti berikut:

Nu modo-nu mea rarik mutu

Rarik mutu ta'ek saren ba malu

Ta'ek saren ba malu-saren kadeli.

Kelapa hijau-kelapa merah tumbuh berdampingan

Tumbuh berdampingan-bunganya saling bertautan

Saling bertautan membentuk cincin. Kiasan ini dikiaskan kepada orang atau kelompok yang berbedabeda hidup dalam kebersamaan dan membentuk cinta sejati tanpa membeda-bedakan.

Malo ami at onan mo se di'ak

Mo se di'ak liutan ami.

Merusak hubungan dengan kami, mau baik dengan siapa.

Baik dengan siapa yang lebih dari kami.

Kiasan ini menunjukan semangat kebersamaan untuk hidup saling berdamai, menghormati dan menghargai satu sama lain.

Kedua, semangat persahabatan dan pelayanan. Bentuk persahabatan yang dibangun dalam masyarakat Bakateu adalah suatu persahabatan yang sehat sebab persahabatan yang sehat dapat membuka ruang bagi relasi dengan orang lain. Orang tidak boleh mengikat dirinya dengan sesama dalam garis horizontal agama dan budaya tetapi membuka diri untuk mengenal sesama di sekitar kita dan orang-orang yang dijumpai. Persahabatan itu harus membawa orang pada tingkat yang saling melayani satu sama lain tanpa memperhitungkan untung dan rugi.

Sama halnya seperti yang terjadi pada masyarakat Bakateu yang telah membangun semangat persahabatan dan pelayanan melalui komunikasi antarpribadi dan interpersonal. Persahabatan yang diciptakan oleh masyarakat Bakateu adalah suatu persahabatan yang terbuka bagi sesama (Apriano 2020). Misalnya ada acara Natal dan tahun baru bersama, acara Idul Fitri dan hari raya besar Islam lainnya yang dirayakan secara bersama-sama di masyarakat Bakateu dalam semangat persahabatan yang saling melayani satu sama lain.

Hal ini dapat diungkapkan melalui kiasan berikut:

"Babotek uma let keta ta kotu

Ta kotu emi let, ami let onan"
Jangan potong putus cecendotan di sekitar rumah

Kalau sudah putus, kamu jauh-kami jauh

Dikiaskan kepada persahabatan itu perlu dibina agar kita tidak saling bermusuhan. Sehingga hidup kita selalu damai dan rukun karena adanya unsur saling menghargai.

\section{"Di'ak-di'ak la nu'u uma no hadak}

Nu'u uma no hadak tetas hakwer"

Baik-baik tidak seperti rumah dengan bale-bale

Seperti rumah dengan bale-bale meratakannya

Dikiaskan kepada kehidupan yang saling menghargai.

Dari persahabatan dan saling menghargai akan membuat orang menjadi bijaksana. Orang bijak pergi kemana saja selalu disukai.

"Derebaban no lia, tala no lia

No lia nala'o dasin oan Wehali to'o mai ti'an,

No lia naman dasin oan Wewiku to'o mai ti'an"

Tihar dan gong berbunyi

Berbunyi sambil mengiring raja Wehali telah tiba Berbunyi sambil mengiring raja Wewiku telah tiba. Dikiaskan kepada seseorang yang baik dan bijaksana, biasanya pergi kemana saja selalu diterima dengan baik.

Kiasan-kiasan ini dimasukan sebagai karakter masyarakat Fehan, di mana masyarakat Fehan hidup dan bergaul dengan "kananuk" (pantun) yang memiliki makna yang sangat mendalam. Kananuk-kananuk ini biasanya digunakan oleh masyarakat fehan untuk menyanjung, menyindir dan bahkan untuk menyambut tamu-tamu agung sesuai dengan konteksnya. Maka dalam konteks persahabatan saya mengutip paling kurang tiga kananuk seperti yang tertulis di atas.

Kata sahabat dalam bahasa tetun/fehan adalah "Belu". Setiap orang yang datang dan hidup membaur dengan masyarakat Fehan/tetun maka mereka dianggap sebagai "Belu" karena kita bersahabat maka kita akan selalu hidup berdampingan.

Ketiga, semangat solidaritas antarumat beragama. Sikap menghargai pribadi manusia harus nampak jelas dalam penerapan prinsip etis solidaritas. Solidaritas bukanlah suatu perasaan belaskasihan yang samar-samar atau rasa sedih yang mendalam sehingga membuat orang lain tergerak hati. Solidaritas merupakan perasaan saling memiliki yang timbul dari hati dan bukan karena rasa kasihan melainkan sebagai rasa senasib dan sepenanggungan (Santoso 2014). Dalam keberagaman terdapat suatu perubahan sosial 
dalam kehidupan (Gunawan 2015). Dan perubahan sosial membawa dampak tranformasi dalam masyarakat.

Bentuk salodaritas yang dibangun dalam masyarakat Bakateu adalah 1) sikap saling menghormati, 2) sikap saling menghargai, 3) saling menolong, dan 4) saling membantu satu sama lain demi mencapai kesejahteraan bersama.

\section{Di'ak itak la nu'u baria lele}

Nu'u barialele lain ba malu

Kebaikan kita tidak seperti tanaman pare Sulurnya selalu saling bertautan. Dikiskan kepada hidup harus saling menolong.

Keempat, Semangat gotong-royong. Gotong royong dalam budaya Fehan dianamakan budaya hakawak. Gotong-royong adalah suatu kegiatan yang dilakukan secara bersama dan bersifat sukarela agar kegiatan yang dikerjakan dapat berjalan dengan lancar, mudah dan ingan. Sikap gotong-royong ini seharusnya dimiliki oleh setiap pribadi manusia dalam lapisan umat; baik umat perkotaan maupun perkampungan atau pedesaan.

Melalui kesadaran dalam dialog antarumat beragama Katolik dan Islam dapat membawa mereka kepada semangat gotong-royong dalam melakukan kegiatan. Dengan adanya gotong-royong, maka semangat persaudaraan dan kerja sama antarpribadi dan kelompok dapat berjalan baik. Kerja sama antarumat beragama Katolik dan Islam dapat ditonjolkan dengan: Pembangunan Kapela dan Masjid serta pelestarian hidup dalam persaudaraan dan perdamaian. Dan bukan hanya itu, kerja sama antarumat Katolik dan Islam juga ada dalam bidang ekonomi yaitu bekerja sawah bersama-sama dan saling mengunjungi satu sama lain dalam semangat solidaritas dan persaudaraan.

Kiasan mengenai kerja sama/gotong royong adalah sebagai berikut:

"Hali badalele sia hali leon di'ak

Leo nola tanotuk karas no kbelan"

Beringin badalele adalah beringin yang baik

Menaungi seluruh penjuru.

Dikiaskan kepada orang yang mampu merangkul semua pihak tanpa pandang bulu.

Hidup dalam masyakat yang plural, setiap pemuka agama, adat, masyarakat harus merangkul semua pihak tanpa membeda-bedakan baik agama, status social, ekonomi, jenis kelamin, suku dan ras. Semua orang dilahirkan untuk saling mencintai, menghargai dan melengkapi satu sama lain.

\section{"Lia anin tatoli keta lai fiar}

Keta fiar lia anin, lia bosok ita

Bosok nalo ita ken kari malu"

Pesan yang dibawa angin jangan percaya

Jangan percaya pesan angin, pesan provokasi

Provokasi membuat hubungan kita menjadi rusak.

Dikiaskan kepada masyarakat agar selalu waspada terhadap setiap pesan yang diterima karena ada pesan yang hanya datang sebagai provakotor yang merusak hubungan yang selama ini sudah terjalin.

\section{SIMPULAN}

Dialog antarumat beragama adalah suatu komunikasi jiwa yang melihat sesama dari agama berbeda sebagai keluarga dan sahabat dalam membangun kehamonisan sehingga tercapainya kesejahteraan bersama melalui semangat solidaritas dan gotong-royong.

Terciptanya kerukunan hidup dalam keberagaman agama, budaya dan suku karena adanya sikap saling menghargai, menghormati satu sama lain. Dan lebih jauh dari semua itu setiap pribadi dari kalangan keberagaman dapat membawakan dirinya dalam masyarakat sebagai satu keluarga, sebagai sahabat dalam membangun semangat solidaritas dan gotong royong demi kesejahteraan bersama. Inilah alasannya kenapa masyarakat Bakateu selama 45 tahun hidup tampa konflik ditengah keberagaman umat beragama.

Larangan untuk tidak mengucapkan Natal oleh oknum Muslim lain tidak memberikan efek bagi umat Muslim lainnya sebab di masyarakat Bakateu, tidak hanya sebatas mengucapkan selamat Natal tetapi juga dapat merayakannya secara bersama dalam lingkup RT.

Keberagaman adalah suatu hadiah dari pencipta untuk saling mengenal ciptaan lainnya, dan bukan hanya saling mengenal tetapi mengcintai, menghormati dan menghargai ciptaan lain sebab keberagamaan datang dari Pencipta yang sama.

Menurut Wahyudi, apabila tidak ada konflik maka organisasi akan mati. Mungkin dalam organisasi boleh dikatakan demikian namun dalam kehidupan masyarakat sangat berbeda. Pada masyarakat Bakateu justeru ada kebanggan tersendiri bahwa daerah mereka tanpa konflik beragama. 
Secara ringkas dapat disimpulkan bahwa tidak pernah terjadi konflik antarumat beragama di Bakateu selama 45 tahun karena adanya sikap saling menghormati dan menghargai yang dibina melalui semangat kekeluargaan, persahabatan, solidaritas dan gotong royong. Suatu daerah yang beragama akan aman maka budayakan budaya kekeluargaan, persahabatan, solidaritas dan gotong royong di dalam kehidupan social.

Sebuah pesan disampaikan kepada umat masyarakat Bakateu dan umumnya yang hidup dalam keberagaman yang telah mengadakan dialog kerukunan anatarumat beragama melalui berbagai jenis kegiatan. Inilah pesannya.

Lia ita ruas dale keta malu'a

Kalan toba malu'a loron manoin

Jangan lupa apa yang telah kita sepakati

Lupa saat tidur malam, ingat saat siang hari. Dikiaskan kepada kehidupan yang harus konsekwen dengan apa yang telah diucapkan dan disepakati.

Lia itak la nu'u manu tatolek

Nu'u manu tatolek lauk nahat

Suara kita tidak seperti ayam tatolek

Seperti ayam tatolek, membuat rusak. Dikiaskan kepada hidup yang tidak boleh meniru perbuatan jahat dari siapapun, karena selalu menghasilkan sesuatu yang tidak baik.

\section{DAFTAR PUSTAKA}

Apriano, Alvian. (2020). "Model Kepemimpinan Kristiani Berbasis Teologi Persahabatan." Pengarah: Jurnal Teologi Kristen,.

Dwintari, Julita Widya. (2018). "Urgensi Pendidikan Kewarganegaraan Berbasis Multikultural dalam Pembinaan Keberagaman Masyarakat Indonesia." Jurnal Ilmu Pendidikan PKn dan Sosial Budaya,

Gunawan, Hanifah .(2015). "Analisis Perubahan Sosial Budaya Masyarakat Desa Cihideung Sebagai Desa Wisata." SOSIETAS.

Husaini, Usman. (2008). "Manajemen: Teori, Praktik dan Riset Pendidikan." SCMS Journal January-March 2008.

Laksmini .(2017). "Teori Interaksionisme Simbolik dalam." PUSTABIBLIA: Journal of Library and Information Science.

Lexy J. Moleong, Dr. M.A. "Moleong, Lexi J. (2014). " Metodologi Penelitian Kualitatif Edisi
Revisi”. Bandung : Remaja Rosdakarya." $P T$. Remaja Rosda Karya.

Rahayu .(2012). "Konsep Keluarga." KELUARGA.pdf., Rifa'i, Afif .(2017). "Dealektika Pemikiran Dalam Dialog Antar Umat Beragama: Studi Kasus Forum Persaudaraan Umat Beriman (FPUB) DI. Yogyakarta." Jurnal Pemberdayaan Masyarakat: Media Pemikiran dan Dakwah Pembangunan.

Rosana, Ellya .(2015). "Konflik pada Kehidupan Masyarakat (Telaah Mengenai Teori dan Penyelesaian Konflik Pada Masyarakat Modern)." Al-Adyan: Jurnal Studi Lintas Agama.

Santoso, Slamet .(2014). "Pola Solidaritas Kelompok Pedagang Angkringan Di Kota Ponorogo." Sosiohumaniora,

Tule, Philipus .(2014). "Religious Conflicts and a Culture of Tolerance: Paving the Way for Reconciliation in Indonesia." Antropologi Indonesia,

Tule, Philipus ..(2014). "The Indigenous Muslim Minority Group In Ma'undai (Keo) of Central Flores: Between the House of Islam and the House of Culture." Antropologi Indonesia.

Utami, Lusia Savitri Setyo .(2015). "Teori-Teori Adaptasi Antar Budaya." Jurnal Komunikasi.

Wahyudi, Andri .(2015). "Konflik, Konsep Teori Dan Permasalahan." Jurnal Publiciana.

Widjaja, Fransiskus Irwan .(2019). "Pluralitas Dan Tantangan Misi: Kerangka Konseptual Untuk Pendidikan Agama Kristen Dalam Masyarakat Majemuk." Regula Fidei. 